\title{
Hydrological exploration in Karst Suaran, Berau, East Kalimantan, Indonesia
}

\author{
Wilda A. Fathoni ${ }^{1 *}$, M. Widyastuti ${ }^{1,2}$, Eko Haryono ${ }^{1,2}$, Hendy Fatchurahman ${ }^{1}$, and M. Ainul Labib ${ }^{1}$ \\ ${ }^{1}$ Karst Research Group, Faculty of Geography, Universitas Gadjah Mada, Indonesia \\ ${ }^{2}$ Faculty Of Geography, Universitas Gadjah Mada, Indonesia
}

\begin{abstract}
Sangkulirang-Mangkalihat is the karst region's identity located on the Mangkalihat Peninsula, on the east side of Kalimantan island. Suaran Karst is a type of karst labyrinth, the typology of karst formed by dissolution in pathways fault, and the fault is more intensive in comparison with other regions. The hydrology expedition in the karst region of Suaran has several objectives, including conducting hydrological observations both briefly and periodically. The discovery of the hydrological and hydrogeological characteristics of the karst region. The various hydrological features found in the Suaran karst region are essential parameters that indicate the uniqueness and importance of the Suaran karst region. The results of the exploration of the karst region of Suaran, found 41 hydrological formations, including springs, pocket valleys, and doline..
\end{abstract}

\section{Introduction}

Sangkulirang-Mangkalihat is the karst region's identity located on the Mangkalihat Peninsula, on the east side of Borneo's island. The Sangkulirang-Mangkalihat karst area has long been used by the community as a residential location, swallow nest collection, and clean water source. One form of karst area management is to establish zones of utilization and protection. The legal instrument available in Indonesia for the protection of karst areas is Minister of Energy and Mineral Resources Regulation No. 17 of 2012 concerning the Establishment of Karst Landscape Areas. The study area is limited to the Suaran karst region, which is upstream (karst) upstream of the Sangkulirang - Mangkalihat karst. Suaran Karst is a type of karst labyrinth, the typology of karst formed by dissolution in pathways fault, and the fault is more intensive in comparison with other regions [1]. Formatting the title, authors and affiliations

Karst Suaran majority are karst hills, and the valley leads to the Northeast - Southwest with some hills also cutting off on minor faults that head south-east. Based on the topography of Suaran karst, a problem often occurs in karst areas is the difficulty of access to water, especially during the dry season. The hydrologic system in karst topography does not allow the availability of large amounts of surface water reserves throughout the year. The number of cavities in the karst area makes it easy for water on the surface to go underground and into groundwater reserves that are quite difficult to access. In karst region, Due to the extensive development of groundwater fissures, pipeline, caves, and groundwater streams causes surface water scarcity, with water rapidly infiltrating underground through the network of karst fissures and conduits in the rock mass. [2],[3],[4].

The karst hydrologic system makes the minimum accumulation of surface water reserves that can be utilized. On the other hand, the loss of surface water and surface runoff that directly enters the soil makes karst aquifers have high potential water resources, especially in terms of quantity. For the community, the spring is one of the resources in meeting water needs. Spring density is affected by several factors, including rainfall, topography, geological structure, permeability, and aquifer characteristics [5]. In the Suaran karst region, the hydrological expedition has several objectives: to conduct hydrological observations both briefly and periodically, discovering the hydrology and hydrogeology characteristics of the karst region.

\section{Method}

The analytical method used in this research is descriptive analysis method. The determination of karst hydrological character was done by tracking the river's flow above the surface and subsurface. This study begins with the interpretation of aerial photographs, geological maps, landform maps, and terrestrial survey planning. The searches were conducted by terrestrial surveys combined with remote sensing data analysis results. The survey tools needed to facilitate research are GPS, field notes, cameras, meters, EC meters, Alkalinity test kit, and $\mathrm{Ca}^{2+}$ test kit.

\footnotetext{
${ }^{*}$ Corresponding author: wilda.aulia.f@mail.ugm.ac.id
} 


\section{Result and Discussion}

\subsection{The Morphology of Suaran Karst}

Suaran Karst is a type of labyrinth karst. Karst labyrinth is a karst typology characterized by karst corridors from hills and intersecting karst limestone blocks. Narrow and steep canyons or valleys separate the series of karst hills that intersect each other. Labyrinth karst formed due to dissolution in fault lines and faults is more intensive than other regions [1].

Labyrinth Karst type is seen in a series of hills that intersect each other. Based on observations, the hills in the Suaran block, the majority of the karst hills, and their valleys lead to the Northeast - Southwest with several hills also cutting in minor faults that run in the Southeast-Northwest direction.

Karst Suaran found several karst geomorphological formations that are quite diverse. Characteristics of karst Suaran in exokarst morphology dominated by dry hills and valleys that develop on the plateau. The development of the dry valleys is controlled by geological structures to form a labyrinth pattern. Karst labyrinth is a karst typology that developed in karst Suaran. Narrow and steep canyons or valleys separate the series of intersecting karst hills. Based on field observations morphologically, the hill formations found in the karst of Suaran have elongated structures with structural patterns such as folds.

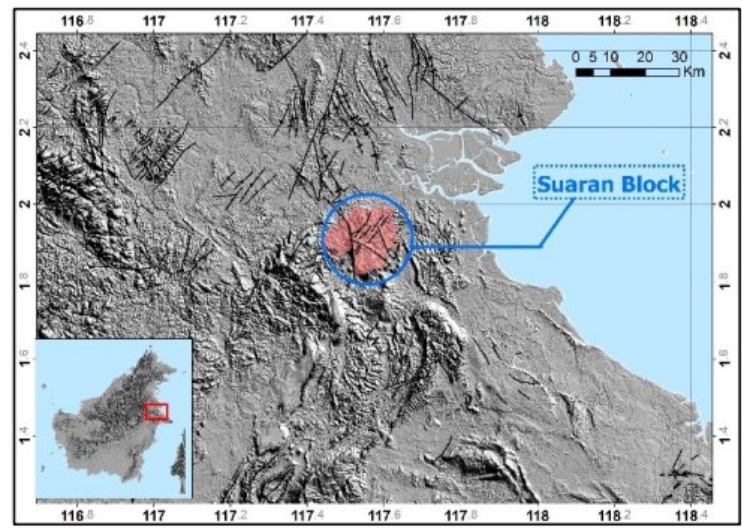

Fig. 1. Location of Suaran Karst Block

Another form of morphology that develops in this karst block is the hill resembling an inverted bowl (conical). The limestone plateau in the Suaran karst region is a fold that has undergone a planation. The karstification process plays a significant role in the development of karst landforms. The consequence of the rock dissolution process, specific conditions will be formed in hydrological and geomorphological aspects. Hydrologically, the developing karst drainage system will form at least two flow systems, namely conduit and diffuse (White, 1988). The heterogeneity of karst aquifers is controlled by the development of fractures, conduit channels, and inter-grain zones. The development of karst landforms will encourage changes in surface morphology. The process of developing a karst landforms is a continuous process that influences one another.

\subsection{The Hydrology Characteristics of Suaran Karst}

Karst hydrology is a water condition associated with the existence, distribution, movement, and quality that exists in the karst region. The water condition in this area is influenced by the nature of carbonate rocks which are the constituents of karst areas. Carbonate rock is a rock that has a characteristic that is there are many fissure cavities and easily soluble in water, causing the surface drainage system in the karst area is not developed and is more dominated by subsurface drainage systems [1].

The existence of a complex hydrological system makes the Suaran karst region have an extraordinary wealth of water resources. The existence of this karst region also has essential value with existing regional hydrological conditions. Karst Suaran functions as a water reservoir because of the presence of water deposits in the karst rock inter-zone and the geological network within it. Karst landform unique landforms is categorizing into one of them is due to a complex hydrological system condition compared to other landforms.

Karst landforms characterized by the development of subsurface tissue, the presence of caves, and closed basins followed by loss of surface flow. Karst hydrological system controlled by a tunnelling system formed by the rock dissolution process, so it is very different from the hydrologic system found in porous media which is generally controlled by the space between the grain of rock. Karst, as a system, has high heterogeneity and uniqueness. Behind the dry surface conditions and scarce water resources, it turns out that the karst region holds extraordinary hydrological potential. Surface rivers found in this area are Suaran River, Kadasah River, Petiwar River and Kuranji River. Suaran River is a large river located on the east side of the Suaran karst. Based on the direction of the flow, Cemening River, Kadasah River, Petiwar River, and Kuranji River are karst rivers that flow into non-karst areas towards the Suaran river.

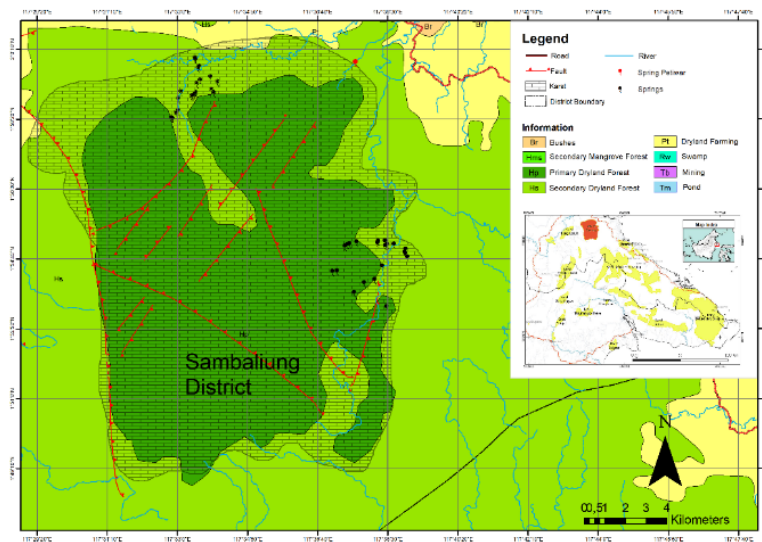

Fig. 2. Map of Distribution of Suaran Karst Hydrological Formations

The various hydrological features found in the Suaran karst region are essential parameters that indicate the uniqueness and importance of the Suaran karst region. Some of the hydrology features in the karst 
region include springs, doline lakes, sinking streams, cave streams, and several other features that have an essential role in maintaining the equilibrium of karst ecosystems.

Here are some descriptions of the characteristics of the hydrological formation found in Suaran karst region:

\section{- Petiwar Spring}

On the north side of the Suaran karst, there is a Petiwar spring. This spring is in Suaran Village, Sambaliung District. Petiwar spring is a resurgence flow with a relatively large and high fluctuating flow rate so that local people call it the Petiwar River. Springs can provide representative data and reflect the conditions of recharge areas [5], [4]. Based on observations, the Petiwar spring water level fluctuation varies significantly with the normal flow conditions ranging from a height of $40 \mathrm{~cm}$. However, during floods, it can reach 4 meters. The water level during a flood can even overflow the river valleys. Petiwar spring conditions are shown in Figure 3.

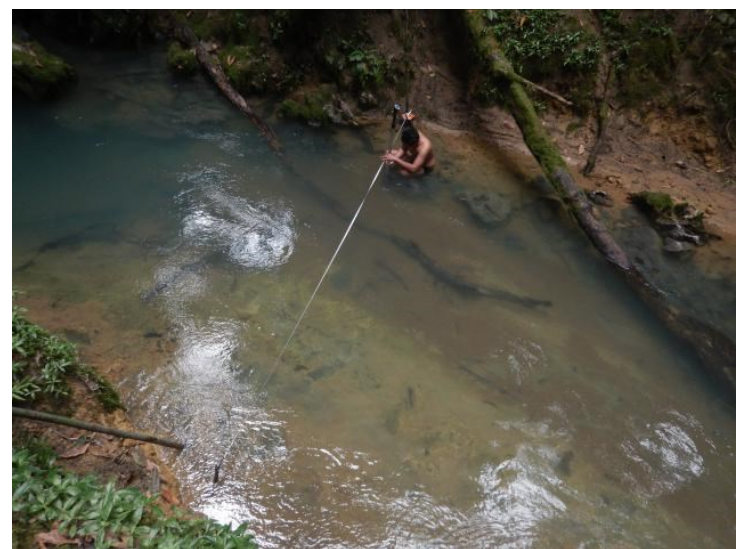

Fig. 3. Petiwar Springs in the Suaran Karst Region, Berau Regency

The minimum debit of Petiwar spring ranges from 500 liters/second, and the maximum discharge reaches almost $7 \mathrm{~m} 3 /$ second. In terms of quantity, of course, Mataair Petiwar has the potential for exploiting very abundant discharge [6]. With the assumption that a spring with a discharge of 1 liter/second can meet the domestic water needs of 1000 people. With this assumption, the minimum debit is enough to meet hundreds of thousands of people's needs. Apart from household needs, the water can be used for other requirements such as agriculture / plantation, livestock, and another needs.

\section{- Mangkajang block}

Mangkajang is part of the East side Suaran Karst. The East Suaran Karst Hills were once opened for logging activities. Logging activity is now no longer active and has become a forest again. Most of the routes used were logged roads that were not used. The hydrology characteristics of the karst were only discovered at a distance of about 18-19 km from Mangkajang Village. The bedrock at that distance is non-karst rock, so there is no hydrological characteristic of the karst. The path to the karst hills passes about 8 major river flows with a dominant flow direction of $300 \mathrm{NE}$. There is one flow at the beginning, which has the opposite flow direction. The rivers will later merge into one stream in the Suaran River, outside the karst area.

The Karst Hills of East Suaran are still undergoing a karstification process. The karstification process is reflected in the form of morphology, speleological formation, hydrological formation, and geology. The initial geological analysis shows that this area is a vadose zone. The hills are not yet in the saturated zone, so the dissolution processes and the formation of the cave passage are still ongoing. The East Suaran karst can be divided into 3 hydrological blocks, including Bram Hill, Kuranji-Jumangut Hill, and Blue Lake. Most springs and surface runoff are perennial and autogenic. Perennial means that it continues to flow throughout the year. Autogenic means that the water source comes from the karst area itself.

\section{- Bram Hill}

Bram hill is an isolated karst hill located to the east of the karst area with an altitude of 200 meters higher than the other hills. Bram hill extends from the North-South direction. Bram hill has its hydrological system and is different from the karst hills around it. At the foot of the Hill came several springs. These springs are generally perennial with small discharge. The large water discharge is only about 8 liters/second. Some springs stagnate and do not form a stream. The type of spring in the bram hill is a conduit. The conduit flow type usually has a significant flow rate because it accumulates many fracture flows (fissures). Water spring in Bram hill is not too big because the catchment area is only on that Hill (autogenic), so it is relatively narrow.

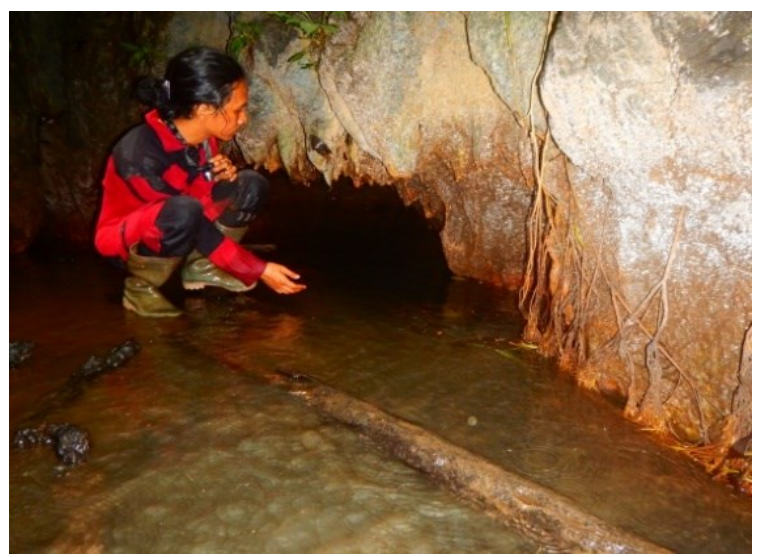

Fig. 4. Hydrology formation Bram Hill in Suaran Karst

Springs founded to the West and East of the Hill. The spring then forms a stream join the Melawang River and ends at the Suaran River. The water quality in Bukit Bram is relatively good. Physically, the water is clear, colorless, odorless, and tasteless.The average $\mathrm{pH}$ content is close to neutral, which is between 7.8-8.4. The value of electrical conductivity (EC) is around 265-281 $\mu$ mhos. The Electrical Conductivity (EC) value indicates that the water is fresh with a low electrolyte 
content. The measured alkalinity includes $\mathrm{Ca}^{2+}$ and HCO3. The alkalinity content comes from dissolving limestone. The content of $\mathrm{Ca}^{2+}$ under normal conditions is tens to $400 \mathrm{gr} / \mathrm{liter}$. If the value of $\mathrm{Ca}^{2+}<40$, it is classified as having low hardness (soft water). Meanwhile, if the value of $\mathrm{Ca}^{2+}>40$ classified as having high hardness (hard water). The $\mathrm{Ca}^{2+}$ content ranges from 58-79 g/liter. it is showed that the $\mathrm{Ca}^{2+}$ content is relatively high, making the water hard. The $\mathrm{HCO} 3$ content ranges from 3.2-3.6 mmol/liter. The content of dissolved oxygen (DO) ranges from 20.5-25.4.

Bram hill has a forest land cover with various types of large trees and shrubs. The trees located on hilltops, slope terraces, and lower plains. So far, the springs and streams in Bram hill have not used for any purpose. Apart from being relatively small in water discharge, the location is also not possible to utilize. Springs and streams only used as a source of drinking water for animals.

\section{- Selung hill}

Selung is on the outer side of the karst hill area. The name of Selung refers to a spring called upstream Selung. The spring then forms a stream called the Selung River. The flow then enters the Buta Selung Valley to become an underground flow/cave. The upstream of the Selung river is in a cave where the passage submerged in water. The characteristics of the cave flooded, so measurement during the flood discharge is around $1.6 \mathrm{M} 3$ / second. It estimated that the catchment area is Mumuk Hill and Sembilan Ratus hill. The direction of the cave passage is $260 \mathrm{NE}$. The water flows towards $11 \mathrm{NE}$. The flows form a Meander run off with a base of limestone bedrock with little mud-river valleys various in-depth, between 1-2 meters lower than their banks. Flow properties intersect direction of rock layers (obsequent). The flow of the Selung river has reached the base level of the local water, so the process of dissolving and deepening the valley is no longer intensive. The flow of the Selung river is calm. Surface flow is about $3 \mathrm{~km}$ or about a 1hour journey between Selung upstream to Selung Cave.

Selung Cave is a series of caves based on the local groundwater level [1]. This cave formed due to erosion by the flow from the Selung River.The river flow then forms an underground flow system. The flow system does not know where it will come out. The output of this underground flow system is likely in the vicinity of Melawang Hill. However, it is necessary to trace the flow first to strengthen this assumption. This flow tracing can use the tracing method.

The quality of spring water and the Selung River is relatively good. The alkalinity content tends to be high with $\mathrm{Ca}$ values between 58-60 gr/liter and $\mathrm{HCO}_{3}$ between 2.8-3.3 mmol/liter. The area around Spring, River, and Selung Blind Valley is a former logging forest area. Currently, forest land cover is already dense. It increases the soil formation process, causes the flow to become increasingly acidic, and accelerates the process of dissolving the rock. Water resources in Selung have not been widely using. So far, it has only used as a source of drinking water for residents who stay at Camp Selung and a source of water for animals.

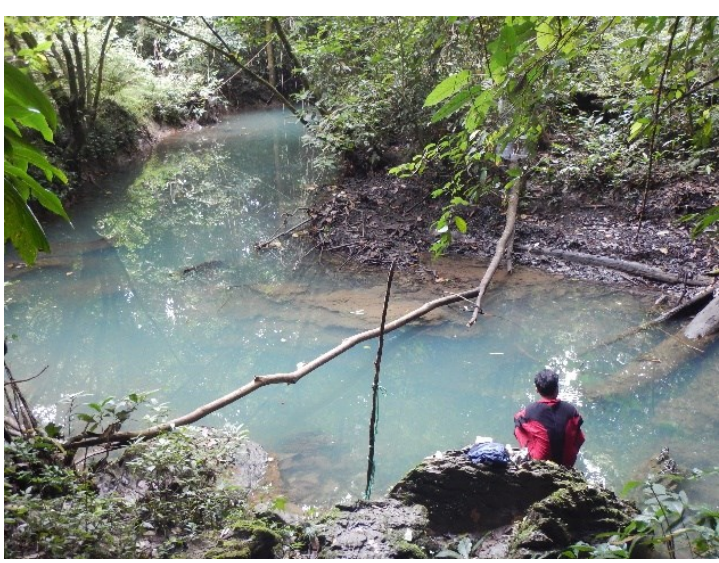

Fig. 5. Selung river in East Suaran Karst

\section{- Blue lake}

Blue Lake is a large doline filled with water. This doline is in the middle of the hills that form a bowl. Blue Lake is almost in the middle of the bowl. The Blue Lake catchment area is most likely a series of Four S Hills. The lake water source comes from springs, which form a runoff of about $500 \mathrm{~m}$ towards the lake. Blue Lake is the end of the flow. Several ponors then continue the water flow. The first ponor is a small hole visible from the surface with a turbulent flow type. The second Ponor is at the end of the lake and located at the bottom of the lake. This is indicated by the presence of a whirlpool in the lake as a place for water to enter. The water then enters the underground river system. It estimates that the groundwater flow passes through the Duabelas Keramat hill and becomes a spring at the base of KuranjiJumangut Hill. This estimate based on information from residents and surface delineations from the map. However, this is uncertain because subsurface karst flows can be very different from the surface formation. Therefore, a more accurate test with the tracing method is needed.

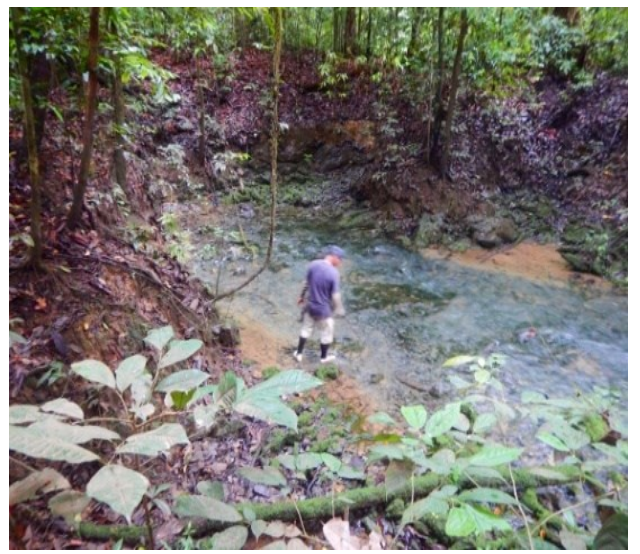

Fig. 6. Selung river in Suaran Karst

The quality of Blue Lake water is generally good. Aesthetically, water is clear with a bluish color due to the carbonate content's influence, tasteless and odorless. The $\mathrm{pH}$ value is around 8.27. The EC value is around $225 \mu$ mhos. The alkalinity content of water is quite high and includes hard water. The $\mathrm{Ca}$ content is $60 \mathrm{gr} /$ liter, 
and the $\mathrm{HCO}_{3}$ content is $3 \mathrm{mmol} /$ liter. The flow rate towards Blue Lake is huge, more than 50 liters/second. Blue Lake is a gathering place for water when it rains. Therefore, the volume of water can increase sharply. The water level can rise more than 3 meters, inundating the surrounding area based on the marks of flooding in the trees.

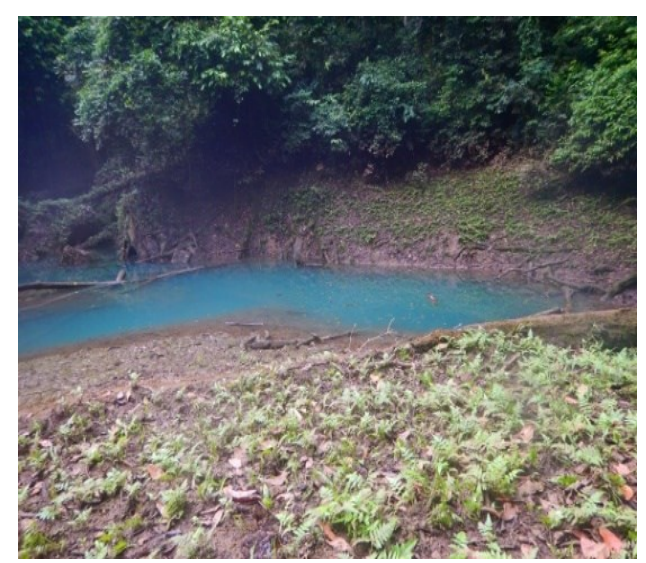

Fig. 7. Blue Lake in East Suaran Karst

The land cover around Blue Lake is still forest. Because it is in a difficult location, it is not have been logging in the past. Around Blue Lake, there is also some doline, both watery and dry. The doline functions as a drain channel. The dolines fill with rainwater, and then it will last for some time before disappearing into the ponor. So far, the Blue Lake area has not been utilizing. This area has the potential to be developed into a tourist destination.

As an ecosystem, karst is an area of unique and highly sensitive (fragile) to environmental degradation. Karst ecosystem sensitivity is mainly due to the thin soil cover and scarcity of surface water that condition brings the ecological consequences about biodiversity and socio-economic. All forms of utilization will give a negative impact on karst ecosystem compared with other ecosystems. Karst ecosystem management thus needs special attention compared to other ecosystems. Good management and sustainability in this case require a true understanding of the karst area.

In managing water resources in karst areas, the policies taken must of course be adjusted to the nature and development of the aquifer. In other words, before management is carried out, a method must be chosen which is adapted to the stages of karst development that is in line with the development of the passage way, the size of the water reserves, and the nature of its flow when supplying underground rivers or springs.

Karst Research Group conducted the expedition in August and October 2016. In Suaran karst, found 41 hydrological formations, including springs, pocket valleys, and doline. The expedition team was assisted by a forest guide to explore the karst forest and to identify the formation of hydrology. Karst Suaran expeditions not carried out on the karst of the west and south sides, and this is because forest guides did not know karst area, the block location is too far away and requires much time. The distribution of hydrologic formations during the expedition much founded on the east side of Suaran
Karst. It is due to the number of karst morphologies and closed basins that can be reached compared to the north side of the Suaran karst.

The various hydrological features found in the Suaran karst region are important parameters that indicate the uniqueness and importance of the Suaran karst region. Some hydrological features in the karst region include springs, doline lakes, sinking streams, cave streams, and several other features that have an essential role in maintaining the equilibrium of karst ecosystems. Distribution of hydrologic formations and chemical characteristics of karst Suaran presented in Table 1.

\section{Conclusion}

Karst Suaran approximately 41 hydrologic formations such as springs, doline, and pocket valleys were discovered and identified. Further research is need to determine character hydrogeology, karst aquifers, and karstification levels for sustainable management of water resources. For recommendations, the expedition should be continued further in other blocks to determine the characteristics of the Suaran karst in detail.

This research is part of a Thesis at the Postgraduate Geography of Faculty of Geography, Universitas Gadjah Mada. This research was funded and organized by Karst Research Group, Faculty of Geography, Universitas Gadjah Mada, collaborating Yayasan KEHATI with funding from the TFCA Kalimantan Program. The authors also would like to thank all people who were joined the expedition.

\section{References}

1. E. Haryono and T. N. Adji. Pengantar Geomorfologi dan Hidrologi Karst. Yogyakarta: Fakultas Geografi UGM (2004). In Bahasa

2. D. Ford, \& P. Williams. Karst Hydrology and Geomorphology. West Sussex: John Wiley \& Sons Ltd (2007)

3. P. W. Williams. The role of the epikarst in karst and cave hydrogeology: a review. Int. J. Speleol. 37, 110 (2008)

4. T. N. Adji. Distribusi Spasial Respon Debit Mataair dan Sungai Bawah Tanah Terhadap Hujan untuk Prediksi Kapasitas Penyimpanan Air oleh Akuifer Karst di Sebagian Wilayah Karst di Pulau Jawa. Yogyakarta. Laporan Penelitian. Yogyakarta. Fakultas Geografi Universitas Gadjah Mada (2016)

5. J. F. Quinlan and A. Stanley. eds., Hydrology, ecology, monitoring and management of ground water in karst terranes conference, 3rd, Nashville, Tennessee, Proceeding: Dublin, Ohio, National Ground Water Association: 573-635 (1991)

6. W. A. Fathoni, Analisis Hidrograf Mataair Petiwar Untuk Karakterisari Akuifer Karst Suaran Yogyakarta: Fakultas Geografi UGM (2019). In Bahasa 
Table 1. Spring data in Suaran karst region

\begin{tabular}{|c|c|c|c|c|c|c|c|c|}
\hline \multirow[t]{2}{*}{ No } & \multirow[t]{2}{*}{ Name } & \multicolumn{2}{|c|}{ Coordinate } & \multicolumn{5}{|c|}{ Chemical Properties } \\
\hline & & $\mathrm{X}$ & $\mathrm{Y}$ & $\mathrm{pH}$ & $\begin{array}{c}\mathrm{EC} \\
(\mu \mathrm{S} / \mathrm{cm})\end{array}$ & $\begin{array}{c}\mathrm{Ca} \\
(\mathrm{mg} / \mathrm{lt})\end{array}$ & $\begin{array}{c}\mathrm{HCO}_{3} \\
(\mathrm{mmol} / \mathrm{lt})\end{array}$ & $\begin{array}{c}\text { Temperature } \\
\left(\mathrm{C}^{0}\right)\end{array}$ \\
\hline 1 & Suaran 1 spring & 562053 & 220834 & 7,66 & 355 & 88 & 7,2 & 25,5 \\
\hline 2 & Suaran 2 spring & 562024 & 220924 & 7,04 & 533 & 124 & 5,6 & 25,0 \\
\hline 3 & Suaran 3 spring & 562184 & 220440 & 7,28 & 509 & 118 & 5,3 & 25,6 \\
\hline 4 & Suaran 4 spring & 562280 & 219844 & 7,52 & 503 & 126 & 5,8 & 25,8 \\
\hline 5 & Suaran 5 spring & 562118 & 219668 & 8,44 & 266 & 52 & 1,4 & 25,3 \\
\hline 6 & Suaran 6 spring & 562070 & 219236 & 8,64 & 456 & 84 & 1,4 & 25,2 \\
\hline 7 & Suaran 7 spring & 561981 & 219127 & 7,58 & 521 & 104 & 5,1 & 25,3 \\
\hline 8 & Suaran 8 spring & 561891 & 219105 & 8,16 & 531 & 94 & 4,5 & 25,6 \\
\hline 9 & Suaran 9 spring & 561864 & 219047 & 8,57 & 416 & 92 & 1,3 & 25,0 \\
\hline 10 & Suaran 10 spring & 561203 & 218946 & 8,59 & 229 & 66 & 0,7 & 24,9 \\
\hline 11 & Suaran 11 spring & 560869 & 218021 & 7,33 & 206 & 58 & 2,4 & 25,1 \\
\hline 12 & Suaran 12 spring & 560946 & 217982 & 8,41 & 237 & 52 & 1,7 & 24,4 \\
\hline 13 & Suaran 13 spring & 561101 & 218255 & 8,34 & 237 & 53 & 1,8 & 24,6 \\
\hline 14 & Suaran 14 spring & 561195 & 218359 & 8,26 & 237 & 54 & 1,9 & 24,5 \\
\hline 15 & Suaran 15 spring & 561343 & 219280 & 8,17 & 237 & 55 & 1,10 & 24,6 \\
\hline 16 & Suaran 16 spring & 562778 & 220007 & 7,55 & 565 & 132 & 5,6 & 25,0 \\
\hline 17 & Suaran 17 spring & 563116 & 219762 & 7,92 & 555 & 130 & 5,6 & 26,2 \\
\hline 18 & Suaran 18 spring & 562829 & 219379 & 7,66 & 409 & 108 & 4,9 & 25,5 \\
\hline 19 & Suaran 19 spring & 562944 & 219230 & 8,22 & 230 & 62 & 4,5 & 25,3 \\
\hline 20 & Kadasah river & 562236 & 220507 & 8,41 & 237 & 58 & 1,7 & 24,4 \\
\hline 21 & Petiwar spring & 570250 & 221959 & 7,2 & 250 & 78 & 2,1 & 23,5 \\
\hline 22 & Melawang pocket valley & 570881 & 211968 & 7.78 & 304 & 64 & 3.3 & 25.6 \\
\hline 23 & Melawang river & 570902 & 212058 & 7.7 & 282 & 41 & 3.2 & 26 \\
\hline 24 & Kuranji river & 569865 & 212018 & 7.9 & 87 & 20 & 1.1 & 27.4 \\
\hline 25 & Jumangut pocket valley & 569515 & 211934 & 8.09 & 229 & 52 & 3.2 & 24 \\
\hline 26 & Jumangut blind valley & 569413 & 211886 & - & - & - & - & - \\
\hline 27 & Jumangut pocket valley & 569293 & 211812 & 8.15 & 230 & 62 & 2.5 & 26.3 \\
\hline 28 & NN spring & 571256 & 211851 & 8.13 & 513 & 69 & 3.2 & 26 \\
\hline 29 & Kolam Kering & 570730 & 210199 & - & - & - & - & - \\
\hline 30 & Selung blind valley & 570225 & 210051 & 8.25 & 280 & 60 & 3.3 & 26.4 \\
\hline 31 & NN river & 571346 & 211902 & 8.17 & 292 & 62 & 2.9 & 25 \\
\hline 32 & NN spring & 571241 & 212063 & 8.17 & 279 & 62 & 3.1 & 25.3 \\
\hline 33 & Damar Cave & 569733 & 209567 & 8.25 & 240 & 66 & 3.1 & 26.3 \\
\hline 34 & Doline water & 568905 & 210621 & 8.28 & 239 & 66 & 3.1 & 26.7 \\
\hline 35 & Blue Lake & 568683 & 210585 & 8.27 & 225 & 60 & 3 & 26.6 \\
\hline 36 & Doline XX & 571670 & 211914 & 8.26 & 309 & 68 & 3.7 & 25.9 \\
\hline 37 & Berkubang spring & 572189 & 211534 & 7.83 & 273 & 60 & 3.2 & 27.1 \\
\hline 38 & Lorong Air & 572221 & 211467 & 7.95 & 275 & 79 & 3.4 & 25.5 \\
\hline 39 & NN pocket valley & 572320 & 211291 & 8.48 & 281 & 62 & 3.6 & 27.4 \\
\hline 40 & Berkubang river & 572232 & 211676 & 8.13 & 265 & 58 & 3.4 & 26.7 \\
\hline 41 & Selung Upstream & 571308 & 208890 & 8.15 & 220 & 58 & 2.8 & 25.6 \\
\hline
\end{tabular}

